Amasya İlahiyat Dergisi - Amasya Theology Journal

ISSN 2667-7326 | e-ISSN 2667-6710

Haziran / June 2020, 14: 229-258

\title{
İnsanın Onuru mu? Mükerremliği mi? \\ Biyoetikte İnsanın Değerinin Temellendirilmesine Yönelik Bir Analiz*
}

\author{
Is The Human Dignity? Is el-Kerâmet'u-Nâs? \\ An Analysis for Fundamentaling of Human Value in Bioethics
}

\author{
Nurten Zeliha ŞAHIN \\ Dr. Öğr. Üyesi, Manisa Celal Bayar Üniversitesi, İlahiyat Fakültesi, \\ İslam Hukuku Anabilim Dalı \\ Assistant Professor, Manisa Celal Bayar University, Faculty of Theology, \\ Department of Islamic Law \\ Manisa, Turkey \\ nurtenzeliha.sahin@cbu.edu.tr \\ orcid.org/0000-0003-0341-6311
}

\section{Makale Bilgisi / Article Information}

Makale Türü / Article Types: Araştırma Makalesi / Research Article

Geliş Tarihi / Received: 4 Mart / March 2020

Kabul Tarihi / Accepted: 26 Nisan / April 2020

Yayın Tarihi / Published: 30 Haziran / June 2020

Yayın Sezonu / Pub. Date Season: Haziran / June

Sayı / Issue: 14 Sayfa / Pages: 229-258

Atıf / Cite as: Şahin, Nurten Zeliha. "İnsanın Onuru mu? Mükerremliği mi? Biyoetikte İnsanın Değerinin Temellendirmesine Yönelik Bir Analiz [Is The Human Dignity? Is elKerâmet'u-Nâs? An Analysis for Fundamentaling of Human Value in Bioethics]". Amasya İlahiyat Dergisi-Amasya Theology Journal 14 (June 2020): 229-258.

\footnotetext{
Etik Bildirim: Bu makale yazarın "İslam Hukuku ve Biyoetik (Sorumluluk ve Özerklik Ekseninde Biyoetik Tartışmalar)” adlı doktora tezinin bir bölümünden türetilmiştir.

Ethical Statements: This article is produced from a part of the author's doctoral thesis called "Islamic Law and Bioethics (Bioethics Discussions in the Axis of Responsibility and Autonomy)"
} 
230 | N. Z. ŞAHİN / İnsanın Onuru mu? Mükerremliği mi? Biyoetikte İnsanın Değerinin Temellendirmesine Yönelik Bir Analiz

https://doi.org/10.18498/amailad. 698420.

Intihal / Plagiarism: Bu makale, en az iki hakem tarafından incelendi ve intihal içermediği teyit edildi. / This article has been reviewed by at least two referees and scanned via a plagiarism software.

Copyright (C) Published by Amasya Üniversitesi, İlahiyat Fakültesi / Amasya University, Faculty of Theology, Amasya, 05100 Turkey. All rights reserved. https://dergipark.org.tr/amailad.

\section{Is The Human Dignity? Is el-Kerâmet'u-Nâs?}

\section{An Analysis for Fundamentaling of Human Value in Bioethics}

\section{Abstract}

Human Dignity is mentioned in international human rights documents as a protective universal value. While human dignity is an intangible right, autonomous choices of human have come to the fore as the determinant of this dignity. It is seen that this concept does not have sufficient protection in terms of people who do not have autonomy or use them in the face of scientific and technological developments. On the other hand, It can be said that mukarram attribution is a concept that is based on the dignity of the human being only human. The mukarram is also a characteristic given to the Qur'an. with this aspect, in Islamic Law, this concept is considered not to touched and changed as an attribute a quality attributed to the human species and It has been given a normative content. This feature has content that protects all human beings and the human body, whether alive or not, in any stage of biologicial life. Because human beings are the only creatures with reason, will and consciousness among other creatures. Therefore, the approach to human should be in a way to protect this repeat indepedently of all religious beliefs and moral attitudes. This study aimed to show that mukarram has an inclusive and protective content of human species in the face of bioethical dilemmas with its content defined in Islamic Law.

\section{Summary}

The expression of human dignity includes a value-based definition of what a person is. The first question that comes to mind when people are defined as a dignity being is what the source of dignity is. The content of a concept is not independent from its meaning, and the content of the meaning is not independent from the world idea where the concept exists. The field that is subject to the most evaluations at the point that human dignity is a value that 
needs to be protected is bioethics. Modern bioethics concept adopts secular and objective principles as it is based on western moral philosophy and biomedicine perspective. In this sense, it keeps the individual and autonomy equal, regardless of cultural ties and beliefs. The principle of autonomy also takes its foundation from human dignity. Because the right to protect one's own identity and dignity is based on her autonomous preferences. This conceptual content has turned human dignity into the basic basis of rights in the demand for individual rights. For this reason, human dignity has begun to form the basis of the opposite claim, which has made this concept uncertain in terms of content. both those who support euthanasia, and researchers on human embryos or advocates and critics of assisted reproductive technologies can use the concept of human dignity. Identification of such opposing rights within the same concept show how uncertain this concept has become. Despite the concept of human dignity, which stands out as a human defining concept in human rights and bioethics, there is a mukarram of human in Islam. In Islam, on the other hand, Şâri has formed the perception that contains value for the human body. It is accepted that, with the qualification of the human body as "mukarram", Şâri' has an obligation to protect herself and to the legal order in which she is protected. el-Kerâmet'u-nâs is a attribute attributed to the humanity in the Qur'an and Its content has been defined by Islamic lawyers in a protective way from all kinds of floods that may occur to her and from all kinds of harmful acts that change human species. This concept aims to protect people as subjects. For this reason, el-Kerâmet'u-nâs is a concept that Islamic lawyers have gained a normative quality to protect people. Since human dignity is focused on the addressee, it is a value containing request from the other side. Therefore, for those who cannot claim their rights from the other side, the protective umbrella cannot be sufficient. el-Kerâmet'u-nâs quality brings responsibility to the subject and this feature includes an inclusive protection for humanity, regardless of human biological life cycle. With this aspect, mukarram refers to a more protective feature in terms of its conceptual content for bioethics that evolves towards protecting the subject, as it only belongs to human existence. In the face of many different dilemmas brought by medicine, genetics and biology today, if the person is given the kind of mukarram nature, it will be protected against all kinds of effects that may lose not only this person of today but also future generations. The source of human dignity is autonomous choices of man. This gives man the right to define his own dignity and to determine how to protect it. The autonomy within this meaning content revealed a result that 
232 | N. Z. ŞAHİN / İnsanın Onuru mu? Mükerremliği mi? Biyoetikte İnsanın Değerinin Temellendirmesine Yönelik Bir Analiz

human can do whatever he wants, as long as he does not harm anyone else on his own body. el-Kerâmet'u-Nâs is defined as the duty of protecting it, primarily as a task which must be fulfilled against its own body, as it is a characteristic given by the creator. In this context, the legal order also has an obligation to make arrangements to protect the the human species. Since human dignity is defined as a qualification of people, it has not yet passed into the stage of existence, but it does not express protection in terms of embryo that has the potential to be human. On the other hand, el-kerâmet'u-Nâs cannot be considered as independent from human identity. For this reason, all the people are included in this respect in terms of being human. This respect does not begin with birth, but with the aspect of belonging to the the human species, starting from the first stage of creation. Because this qualification is not given to man, but to human type. As the human species does not change after the embryo phase, it also does not change its respectability. In addition, mukarram is a valid feature in every stage of human biological life. Therefore, there is no life that can be overlooked by saying that one of the biological stages of human beings has more rights to medical support than the other. el-Kerâmet'u-nâs has transformed it into a respectable, legally protected value. This value is attributed not only to the person but also to her body, whether it is in her body or not, and this qualification is made unique to the human body regardless of life and death. Islamic jurists acted with the dignity and innocence when it comes to human beings. For this reason, el-Kerâmet'u-nâs as a legal value that needs to be protected, it has included the next generations in this protection. With this aspect, it should be noted that the mukarram qualification will be more effective and functional in terms of the protective nature of the human species in bioethical dilemmas and its content is more distinctive and identifiable than human dignity.

Keywords: Islamic Law, Bioethics, al-Mukarram, The Human Dignity, alMuhtaram.

\section{İnsanın Onuru mu? Mükerremliği mi?}

Biyoetikte İnsanın Değerinin Temellendirmesine Yönelik Bir Analiz

\section{Öz}

İnsan onuru, uluslararası insan hakları belgelerinde insanı koruyucu evrensel bir değer olarak geçmektedir. İnsan onuru dokunulamaz mutlak bir hak olması ile birlikte insanın özerk seçimleri bu onurun belirleyicisi olarak öne çıkmıştır. Bilimsel ve teknolojik gelişmeler karşısında özerkliği bulunmayan veya 
kullanamayan insan açısından bu kavramın çokta yeterli bir koruyuculuğu olmadığı görülmektedir. Buna karşılık insana yüklenen mükerremlik vasfının, insanın sadece insan olmasıyla saygınlığını temel alan bir kavram olduğu söylenebilir. Mükerremlik Kur'an da âdemoğluna verilen bir vasıftır. Bu yönü ile İslam Hukukunda bu kavram, insan türüne yüklenen ve dokunulamaz, değiştirilemez olan bir vasfın ifadesi olarak ele alınmış ve ona normatif bir içerik kazandırılmıştır. Bu vasıf, biyolojik yaşamın hangi evresinde olursa olsun bütün insanları ve canlı olsun olmasın insan bedenini koruyucu içeriğe sahiptir. Çünkü insanoğlu diğer yaratılmışlar arasında akıl, irade, bilinç sahibi tek varlıktır. Bu yönü ona kendi varlığını yaratıldığı şekli ile koruma sorumluluğu yüklemektedir. Bu nedenle insana yaklaşım, her türlü dini inanç ve ahlaki tutumundan bağımsız olarak bu mükerremliğini koruyacak şekilde olmalıdır. Bu çalışma, mükerremliğin, İslam Hukukunda içeriği tanımlanmış şekli ile biyoetik ikilemler karşısında insan türünü kapsayıcı ve koruyucu bir niteliğe sahip olduğunu göstermeyi amaçlamıştır.

Anahtar Kelimeler: İslam Hukuku, Biyoetik, Mükerremlik, İnsan Onuru, Muhteremlik.

\section{Giriş}

İnsan onuru ifadesi, insanın ne olduğuna dair değer içerikli bir tanımlama içerir. İnsanın onurlu bir varlık olarak tanımlanması ile ilk akla gelen soru, onurun kaynağının ne olduğudur. Türkçe sözlükte geçen onur kelimesinden yola çıkılacak olursa onurun birinci kaynağ toplumun kendisidir. Toplumun kişiye gösterdiği sayg, kişisel değer, şeref ve itibar insan için tanımlanan onurun kaynağını oluşturmaktadır. $\mathrm{Bu}$ yönü ile baktığımızda onurun elde edilebilmesinde kişisel bir çabanın yer alması ve elde edilen bu itibarın korunabilmesi için ise kişinin sorumluluk yüklenmesi gerekmektedir. Onur ikinci anlamı ile kaynağını kişinin kendisinden alır. Bu tanıma göre kişinin kendisine karşı duyduğu saygı, şeref, özsayg1, haysiyet, izzetinefis insan onurunun kaynağıdır. Bu tanımlama ise kişinin kendi onurunu nasıl koruyacağıyla ilgili muameleyi belirleme hakkını ortaya çıkartmaktadır. ${ }^{1}$

Uluslararası sözleşmelerde, hukuk metinlerinde yer alan insan onuru bugün kaynağını insanın özerkliğinden almaktadır. İnsanın kendi

1 Türk Dil Kurumu Sözlükleri (TDK), “Onur”, (Erişim 30 Ocak 2020); Nagehan Gürbüz, Biyotıp Hukukunda İnsan Onuru (İstanbul: On İki Levha Yayıncılık, 2014), 11. 
234 I N. Z. ŞAHİN / İnsanın Onuru mu? Mükerremliği mi? Biyoetikte İnsanın Değerinin Temellendirmesine Yönelik Bir Analiz

onurunu belirlemede ve korumada insana yetki veren bu kavramsal içeriği en yakın kullanan Kant olmuştur. Kant, insan onurunu insanın özerkliğine bağlayarak bu kavrama seküler bir içerik kazandırmıştır. ${ }^{2}$ Kant'ın teorisinin temelinde, irade sahibi olarak insanın özerk bir varlık olması yatar. İnsanın akıllı ve özgür olması, onu özerk kılar. İnsan, özerk bir varlık olursa o zaman ahlak yasasına uygun davranabilir. ${ }^{3} \mathrm{Bu}$ tanıma göre insanların kendi aklıyla ulaşabilecekleri evrensel ilkeler doğrultusunda iradeleri ile davranma ödevi, insanı özerk bir varlık kılmaktadır. Fakat bugünkü anlamı ile kullanılan özerklik, Kant’ın tanımladığı şekli ile bir özerklik değildir. ${ }^{4}$ Bugün özerkliğin daha çok özgürlük, bireysellik, kişinin kendini tanımladığı şekli ile kendisini gerçekleştirmesini, kendi menfaati doğrultusunda davranmasını içerecek şekilde tanımlandığı görülmektedir. Bu yönü ile insanın kendi onurunu korumak, kişinin özerk seçimleri çerçevesinde şekillenmmiştir. Başkasına zarar vermediği müddetçe kişilerin tercih ve seçimlerine saygı göstermek, insan onurunun bir gereği olarak ortaya konulmuştur. ${ }^{5}$

İnsan onurunun korunması gereken bir değer olduğu noktasında en çok değerlendirmelere konu olan alan ise biyoetiktir. "Canlı etiği" olarak Türkçe anlamı verilebilecek bu terim tıp, genetik ve biyoteknolojideki gelişmelerin ortaya çıkardığı etik sorunların tartışıldığ gelşmeler ile toplumsal ve kültürel değişimler bu alanın ilk defa 1960'ların başında tanımlanmaya başlamasını getirir. ${ }^{7}$ Bu dönemde tıbbi gelişmeler ile birlikte özellikle biyomedikal araştırmalarda insanın denek olarak kullanılması gibi etik sorunların görünür hale dönüşmesi, biyoetik ilkelerin ortaya konulmasını zorunlu kılmıştır. 1978'ler de ABD'de insanların deneylerde denek olarak kullanımında uyulması

2 Nihat Bulut, “Eski Yunan'dan Aydınlanma Çă̆ına İnsan Onuru Kavramının Gelişimine Genel Bir Bakış", Erzincan Üniversitesi Hukuk Fakültesi Dergisi 12/3-4 (2008), 8-10.

3 Nazime Beysan, Hak Kavramının Hukuk Felsefesi Açısından Analizi (İstanbul: On İki Levha Yayıncilık, 2015), 118-121.

4 Onora O'neill, Autonomy and Trust in Bioethics (Cambridge: Cambridge University Press, 2004), 83-84.

5 Gürbüz, Biyotıp Hukukunda İnsan Onuru, 26.

6 Burcu Kalkan Oğuztürk, Türk Medeni Hukukunda Biyoetik Sorunlar (İstanbul: Vedat Kitapçılık, 2011), 96.

7 Oğuztürk, Türk Medeni Hukukunda Biyoetik Sorunlar, 99. 
gereken kuralların belirlendiği Belmort Raporu yayınlanır. Bu rapor "özerkliğe saygı","faydacılık" ve "adalet" ilkelerini tanımlayan ilk resmi belgedir. ${ }^{8}$ Amerikalı iki tıp etikçisi, Tom L. Beauchamp ve James F. Childress'ın "Biyomedikal Etik Prensipler" (Principies of Biomedical Ethics) isimli kitaplarında bu üç ilkenin yanına "zarar vermemek" ilkesini eklemişler ve böylece biyoetikte başlangıç itibari ile dört tane temel etik prensip benimsenmiştir. ${ }^{9}$ Bu ilkelerden özerkliğe sayg1 ilkesi yaşanan toplumsal ve kültürel gelişmeler ile birlikte kişinin kendi bedeni üzerinde karar verme hakkını genişleten bir ilke olmuştur. Modern biyoetik kavramı batının ahlak felsefesine ve biyotıp perspektifine dayandığı için seküler ve objektif ilkeleri benimsemektedir. Bu anlamda kültürel bağ ve inanışlardan bağımsız olarak bireyi ve özerkliği birbirine eşit tutmaktadır. ${ }^{10}$ Özerklik ilkesi de temelini insan onurundan alır. Çünkü kişi kendi kimliğini, onurunu koruma hakkı onun özerk tercihlerine dayanır.

İslam'da ise insan bedenine yönelik değer içerikli algıyı, Şâri' oluşturmuştur. Şâri'in insan bedenini "mukerrem" olarak vasıflandırmasıyla bu vasfın korunması noktasında kişinin kendisine ve bulunduğu hukuksal düzene koruma yükümlülüğü yüklediği kabul edilmiştir. Dünya Sağlık Örgütü tarafından yayınlanan İslam etik kodunda birinci ilke olarak insanın mükerrem olarak yaratıldığı ifade edilmekte ve bu vasfın insanın kendi sağlığını muhafaza etme sorumluluğunu getirdiği gibi sağlik çalışanlarına da insanın mahremiyetine dikkat etmek yükümlülüğünü getirdiği belirtilmiştir. ${ }^{11}$ Bu yönü ile İslam' da biyoetik kişinin hem kendisine ve hem de çevresine yönelik yerine getirmesi gereken sorumluluk eksenlidir. Bu bağlamda bu çalışma insanın özerkliğini temel alan insan onuru ile insana insanlık vasfını koruma sorumluluğu veren mükerremlik vasfının biyoetik ikilemlere yaklaşım noktasında bir değerlendirmeyi içermektedir.

8 Office for Human Research Protections (HHS), "The Belmont Report", (Erişim 09 Nisan 2020).

9 Tom L. Beauchamp - James E. Childress, Biyomedikal Etik Prensipler, çev. Kemal Temel (İstanbul: Betim Kitaplığı, 2017), 20.

10 Mehmet Ali Zengin, Biyoloji Uygulamaları ve Tıbbi Müdahaleler Karşısında İnsan Haklarının Korunması (Ankara: Adalet Yayınevi, 2012), 67.

11 "İkinci ilke adalet, üçüncü ilke eşitlik, dördüncü ilke ihsandır". World Health Organization Regional Office for the Eastern Mediterranean. (WHO). "Islamic Code of Medical and Health Ethics", (Erişim 09 Nisan 2020). 
236 | N. Z. ŞAHİN / İnsanın Onuru mu? Mükerremliği mi? Biyoetikte İnsanın Değerinin Temellendirmesine Yönelik Bir Analiz

Çalışma öncelikle insan onurunun biyoetikteki kullanılması ile ortaya çıkan muğlaklığa değinecek ve bu noktada Kur'an da insana yüklenen mükerremliğin tıp, biyoloji ve genetiğin ortaya çıkardığı ikilemler karşısında insan türünü daha kapsayıcı bir şekilde koruyucu rolünün olup olmayacağı üzerinde duracaktır.

\section{Biyoetik ve İnsan Onuru}

İnsan onuru kavramı bugünkü yaygın kullanım içeriği ile uluslararası sözleşmeler ve hukuksal metinlerde yer alan "the human dignity" tamlamasının Türkçe karşılığıdır. "İnsan onuru" evrensel bildirge ve onu takip eden belgelerde insanın insan olmasından kaynaklanan eşit hak ve özgürlüklere sahip olmasının temel dayanağı olarak görülmektedir. Batı'nın yaşadığı İkinci Dünya Savaşı'nda insan haklarına yönelik ağır ihlaller karşısında insanlığı bir değer olarak koruma refleksinin gelişmesi, uluslararası deklarasyonlarda insan türünü koruyucu olarak "insan onuru" ifadesine yer verilmesine neden olmuştur. İnsan onuru evrensel hukuk diline ilk olarak 1948 yılında İnsan Hakları Evrensel Bildirgesinde "the inherent dignity" şeklinde geçen tanımlama ile girer ve böylece kişinin kendi içsel değerinden kaynaklanan onuru ${ }^{12}$ hukuken korunması gereken bir değer haline dönüşür. Daha sonraki yayınlanan uluslarası belgelerde ve ulusal yasalarda insan onuru, normların kendisinden türetilecek bir değer şeklinde tanımlanarak insan onuruna aykırı olan bir normun hukuk diş1lığ ortaya konmuştur..$^{13}$

Uluslararası belge ve hukuksal metinlerde geçen insan onuru ile insanda içkin olan ve tüm insanlarda eşit olarak var olan bir değerden söz edilmektedir. Deklarasyonlar vasitası ile insan onurunun bu anlamının öne çıartılması yaşam, fiziksel bütünlük, mahremiyet gibi hakların korunmasının hukuki dayanağını insan onurundan almaya başlamasını getirir. Daha sonraki süreçte insan haklarına ilişkin bölgesel sözleşmeler ve anayasal metinler devreye girdiği zaman bu belgeler

12 “İnsanlık ailesinin bütün üyelerinin doğal yapısındaki onuru ile eşit ve devredilemez haklarını tanımanın dünyada özgürlük, adalet ve barışın temeli olduğunu göz önüne alarak" Insan Hakları Derneği (IHH), "İnsan Hakları Evrensel Bildirgesi", (Erişim 13 Şubat 2020).

13 Elif Çelik, İnsan Onurundan İnsanın Kırılganlığına: İnsan Haklarının Temelinde Yatan Kavramları Yeniden Ele Almak (Ankara: Hacettepe Üniversitesi, Sosyal Bilimler Enstitüsü, Doktora Tezi, 2015), 59. 
vasıtası ile korunan insan onurunun çok farklı görünümleri ortaya çıkmış ve insan onurunun hangi hak ile bağlantısı olduğuna dair tartışmalar belirginleşmiştir. Bu bağlamda sağlık, barınma, çalışma ve iyi yaşam gibi farklı hakların insan onurunun hak talebinin temelini oluşturmaya başladığı görülmektedir. ${ }^{14}$ Bununla ilgili örnek, 1990'a kadar Avusturalya, Fransa ve Amerika gibi bazı ülkelerde gece klüplerinde oynanan bir oyunun mahkemeye konu olmasıdır. Koruyucu elbise giydirilmiş cüceyi, el üstüne alarak en uzağa atma yarışması olarak bilinen oyun, kamu düzenini ve sağlığını etkilediği gerekçesiyle valilik tarafından yasaklanınca, Bay Wackeinheim dava açar ve ilk derece mahkemesi gerekçeyi geçersiz sayarak yasağı yersiz görür. Konu Yüksek Mahkemeye taşınır. Yüksek Mahkeme kamu düzeninin geniş yorumu olarak insan onuruna dayanmış ve oyunu yasaklamıştır. Diğer taraftan Bay Wackeinheim konuyu Birleşmiş Milletler Sivil ve Politik Haklar Sözleşmesi'nin bir organı olan İnsan Hakları Komitesine taşırken savını kendisinin çalışma hakkına ilişkin seçim yapabilmesinin ve özerkliğinin engellenmesi ile insan onurunun çiğnenmiş olduğuna dayandırır. ${ }^{15} \mathrm{Bu}$ davada mahkeme insan onurunu toplumsal bir değer olarak ele almış, buna karşılık davacı taraf yasağı insan onurunun ihlali olduğunu öne sürmüştür. Dava bu yönü ile insan onurunun iki zıt talebin hukuksal gerekçesine dayanak olabilirliğinin bir örneğini teşkil etmektedir. Diğer bir örnek ise eşcinsel evliliğin yasal olmamasının, ayrımcılık yasağı ile insan onurunun ihlali olduğu ileri sürülerek hak talebine dönüşmesidir. Eşcinselliğin bireysel hak temelinde insan onuruna dayandırılması, geleneksel ailenin yapısının korunmasını ve toplumun menfaatini kadın ve erkeğin evliliğinde gören diğer grupların bir noktada hak taleplerinin önünü kesmiştir. ${ }^{16}$ Çünkü insan onuru mutlak, dokunulamaz, eleştirilemez, değiştirilemez bir insani değer olarak tanımlandığı zaman insan onuru içinde tanımlanan bir hak, bütün insanlar için geçerli olan insani bir değer haline dönüşmektedir.

14 Çelik, "İnsan Hakları Hukukunda İnsan Onurunun Yeri ve Önemi", Hacettepe HFD 9/2 (2019), 288.

15 Neomi Rao, "Three Concepts of Dignity in Constitutional Law", Notre Dame Law Review 86/1 (2011), 226-227.

16 Neomi Rao, "The Trouble with Dignity and Rights of Recognition", Virginia Law Review 99/1 (2013), 34; Nurten Zeliha Şahin, “İslam Hukuku ve İnsan Hakları Bağlamında Eşcinsellik Sorunu", Ekev Akademi Dergisi 19/62 (Bahar 2015), 515, 526. 
238 | N. Z. ŞAHİN / İnsanın Onuru mu? Mükerremliği mi? Biyoetikte İnsanın Değerinin Temellendirmesine Yönelik Bir Analiz

$\mathrm{Bu}$ anlamda insan onurunun kişinin kendi bireysel tercihleri noktasındaki taleplerine temel olarak kullanılması aslında insan türünün değerlerini korumayı amaçlayan diğer görüşleri, bu değeri koruma dişına taşır.

İnsan onuru ile bir tarafta içkin ve bütün insanlar için eşit bir değerden söz ederken insan onurunun gerçekleşmesi için özerklik ve eylem içermesi gerekir. O zaman insan onuru ile ilgili böyle bir tanımsal içerik, henüz özerk olmayan veya hiç olmayacak olan insanların insan onuru tanımının dişında bırakıp bırakmayacağı sorusunu gündeme getirecektir. ${ }^{17}$ Örneğin, Avrupa İnsan Hakları Biyotıp Sözleşmesinin birinci maddesinde sözleşmenin biyoloji ve tıbbın uygulamaları karşısında onuru korunacak olanın insan olması ile insan kavramının kimleri kapsadığı ile ilgili bir belirsizliği ortaya koymuştur. Bu yönü ile embriyonun bu koruma alanın dışında bırakıldığı sonucu çıkmaktadır. ${ }^{18}$ İnsan onurunun, insan hakları zeminin de insanın özerk iradesi temelli hak talebinin bir nedeni haline gelmesi, özerk iradesi bulunmayanlar açısından bu korumanın içine dahil edilip edilmeyeceği soru işaret olarak kalmaktadır. Diğer taraftan ise genom bilimindeki gelişmeler ile birlikte üreme amaçlı klonlama ve germ-hattı müdahalelerinin UNESCO'nun yayınladığı İnsan Genomu ve İnsan Hakları Evrensel Bildirgesi'nde insan onuruna aykırı olduğu da kabul edilmiştir (mad.24). ${ }^{19} \mathrm{Bu}$ yönü ile aynı kavramın uluslararası sözleşmelerde hem yetkinlendirici hem de kisitlandırıcı anlamı ile kullanıldığ 1 görülmektedir. $\mathrm{Bu}$ nedenle insan onuru seküler bakışın kendisine yüklediği anlam içeriği içinde özellikle biyoetik alanda yorumuna ve uygulamasına yönelik belirsizliğe dair eleştirilere maruz kalmaktadır. İnsan onuru, açı çeken bir kişinin ölmekte yardım etmeyi haklı çıkartacağ1 gibi diğer taraftan da kişinin yaşamına sayg1 anlamına geldiği şeklinde yorumlanabilir. Onur, aynı zamanda insan üreme klonlaması veya genetik cinsiyet seçimi gibi etik dışı olarak görülen uygulamalarda mücadele için kullanılmaktadır. Bu anlamda biyoetikte insan onuru birbirine zıt taleplerin hak temelini oluşturmaktadır. Uzun

17 Çelik, İnsan Onurundan İnsanın Kırılganlı̆̆ına, 38.

18 Zeynep Kıvılcım-Forsman, "Avrupa Konseyi İnsan Hakları ve Biyo-tıp Sözleşmesi”, İnsan Hakları Yıllığı (1999-2000) 21-22/97; Gürbüz, Biyotıp Hukukunda İnsan Onurur, 58.

19 UNESCO Türkiye Milli Komitesi, “İnsan Genomu ve İnsan Hakları Evrensel Bildirgesi", Erişim 09 Nisan 2020. http://www.unesco.org.tr. 

Human Value in Bioethics I 239

süredir tıbbi destek ile yaşayan hastanın ailesinin bu tıbbi desteğin kesilmesi talebi; yumurtalıklarını kaybettikten sonra eski kocasından spermi ile döllenmiş olan emriyonun rahmine yerleştirilmesi talebi; kişinin aynı cinsiyet ile evlenme talebi; doğmadan engelli geleceği öngörülmediği ve engelli olarak doğmasına izin verildiği için tazminat talebi, insan onuru kapsaminda mahkemelerden talep edilen haklardan bazılarıdır. ${ }^{20}$ İnsan onuru terimini, hem ötenaziyi destekleyenler hem de insan embriyosu üzerindeki araştırmacılar veya yardımcı üreme teknolojileri savunucuları ve eleştiricileri kullanabilmektedir. ${ }^{21}$ Bu kadar zıt hakların aynı kavram içinde tanımlanması bu kavramın ne kadar belirsiz hale dönüştüğünü gösterir. ${ }^{22}$

Britanyalı Tıp Etikçisi Ruth Mackline bu kadar birbirine zıt karar içerikleri bulunan biyoetik konularda insan onuruna dayanılmasının, insan onurunun hangi hakları koruduğuna dair içeriği belirsizleştirdiğine dikkat çekmiştir. Mackline insan onurunun insan özerkliğine sayg1 anlamında biyoetik konularında kullanılmasının elverişli olmadığını belirtir. Mackline, insan onurunun bugün için kendisine verilen anlam içeriğine bakıldığı zaman bu kavramın aslında kişilerin özerkliğine saygıdan başka bir şeyi ifade etmediğine ve bu yönü ile insan onuru ifadesinin olsa olsa birinin özerkliğine sayg1 göstermek olduğuna işaret eder. ${ }^{23}$ İnsan onuru, kişinin kendi onurunu koruyucu şekilde kendisine nasıl davranılması gerektiğini belirlediği gibi insan onuruna sahip bir varlı̆̆ın temel hakkı olan onurluca muamelenin ne olduğunu da belirler. Bu yönü ile insan onuru eylem odaklıdır. Eylem odaklı sorular yasaklar üzerinden değil de haklar üzerinden sorulur ve insan haklarını insanlık onuruna dayandırmak için

20 Luís Roberto Barroso, "Here, There, and Everywhere: Human Dignity in Contemporary Law and in the Transnational Discourse", Boston College International and Comparative Law Review 35/2 (2012), 331-332.

${ }_{21}$ Heike Baranzke, Batıdaki Biyomedikal Etik Tartışmalarında Özerklik ve İnsanlık Onuru, çev. M. Kemal Temel (İstanbul: Betim Beşikçizade Tıp ve İnsani Bilimler Merkezi, 2018), 13.

22 Judge Chrıstian Byk, "Is Human Dignity a Useless Concept? Legal Perspectives", The Cambridge Handbook of Human Dignity Interdisciplinary Perspectives, ed. Marcus Düwell vd. (Cambridge: Cambridge University Press, 2014), 363.

23 Ruth Macklin, "Dignity is a Useless Concept", British Medical Journal 327/20-23 (December 2003), 1419-1420. 
240 | N. Z. ŞAHİN / İnsanın Onuru mu? Mükerremliği mi? Biyoetikte İnsanın Değerinin Temellendirmesine Yönelik Bir Analiz

özne odaklı perspektif yerine muhatap odaklı perspektiften bakılır. ${ }^{24} \mathrm{Bu}$ nedenle özerklik üzerinden tanımlanan bir insan onurunun henüz otonom olmayan veya hiç olmayacak olanların onurunu dişında bırakıp bırakmayacağı sorusunu ortaya çıkartmaktadır. Bu yönü ile gerek insanların genelini ve özerk hayatların bazı dönemlerini düşündüğümüzde insan onurunun varlığı tartışmalı hale dönüşecektir. ${ }^{25}$

Bir kavram kendi içeriği ile birlikte gelir ve bu içerik bazen bir toplumun, bir geleneğin dünden bu güne oluşturduğu yaşama bakışını içeren bir yapıyı da beraberinde getirir. İnsan onuru kavramının içeriği sekülerleşen batı toplumunda, toplumun kendi bireysel yapısını destekleyici şekilde gelişmiştir. Müslüman toplumu olarak insan onuru, onu yaratanın ona verdiği değerden bağımsız değildir. Bu değerde Kur'an da ifade edilen mükerremlik vasfıdır. Bu vasıf insanı yeryüzündeki yerini tanımlayan bir vasıftır. Bu vasfı, İslam hukukçuları hukuki boyuta çekerek normatif bir içerik kazandırmışlardır. Bu makale tıp, genetik bilimi ve biyoteknolojinin ilerlemesi ile birlikte ortaya çıkan etik ikilemeler karşısında insana verilen mükerremlik vasfının, fakihlerin tanımladıkları içerik ile birlikte, insan türünü sadece insan varlığına ait olması yönü ile kapsayıcı ve koruyucu işlevinin olduğu fikri üzerine temellendirilmiştir.

\section{2. İnsanın Mükerremliği - Kerametu'n-Nâs}

İnsan kendiliğinden, vazgeçilmez ve doğuştan bir değere sahiptir. Bu genel kabul ile birlikte bu değerin iki temeli vardır. Birincisi semavi dinler odaklı metafizik yaklaşım; ikincisi insan onurunu özerklik ile bağlantılı olarak ele alan seküler bakış. ${ }^{26}$ Perry, insan hakları temelli bir insan onurunun ancak metafizik temellendirme ile açıklanabileceği görüşündedir. Ona göre her insanın doğasından gelen bir onura sahip olduğunu ve bu onurun dokunulamazlığını söylemek, kaçınılmaz olarak onun varlığını kutsala bağlamak demektir. Perry, "her insanın aynı ailenin bir üyesi olarak doğasından gelen bir onura sahip olduğu'na dair bir konuşmayı dini bir konuşma olarak anlarız, fakat böyle bir konuşmayı seküler olarak anlayabilir miyiz?" şeklinde bir soru ile insanın onurunun metafizik temeline işaret etmektedir. ${ }^{27}$

24 Baranzke, Batıdaki Biyomedikal Etik Tartışmalarında Özerklik ve İnsanlık Onuru, 22-23.

25 Çelik, İnsan Onurundan İnsanın Kırılganlı̆̆ına, 38.

26 Çelik, Insan Onurundan İnsanın Kırılganlığına, 38.

27 Michael J. Perry, The Idea of Human Rights (Oxford: Oxford University Press, 1998), 16. 
İslam'da insan saygınlığını, onu yaratanın ona verdiği değerden alır. "Biz âdemoğlunu keremli kıldık" (el-İsrâ, 17/70) ayeti insanı yaratanın, ona verdiği bir vasfı ifade etmektedir. Mükerremlik vasfı dini inançtan bağımsız olarak kadın ve erkek bütün insanları, biyolojik yaşam aşamasının hangi devresinde olursa olsun kapsayan "âm" bir lafızdır. Alûsî (ö. 1270/1854) Rûhu'l-meâni'de İsrâ 70. ayeti tefsir ederken iyi veya kötü olsun bütün insanların kerem sahibi olduğunu belirterek dini inanç ve ahlaki tavırlardan bağımsız keremlik vasfının bütün insanlara verildiğine işaret eder. Bu anlamı ile insana verilen bu üstünlük ve şeref herhangi bir hasr ifade etmeksizin bütün insanları içine almaktadır. ${ }^{28}$ Çünkü âdemoğlunun keremli kılınması bu kökten gelen herkesin bu keremlik içine dahil edilmesini getirir. Çocuk, kadın veya erkek farketmeksizin insan olmaları yönü ile insan türü kendisi itibari ile mükerremdir. ${ }^{29}$ İnsan için bu yüksek mertebeyi Allah insana has kılmıştır ve insanlığa da bu keremliğin koruması için sorumluluk yüklemiştir. ${ }^{30}$

İsrâ 62. âyette meleklerin Âdeme secde edin emrini alınca şeytan “... benden üstün tuttuğun kişi bu mu, söyler misin..." (el-İsrâ, 17/62) olarak "kerrame" fili ile insana yüklenen üstünlük vasfına işaret edilmektedir. Bu ayeti İsrâ 70. ayet ile birlikte okuduğumuzda Âdem'e verilen bu üstünlügüun ondan gelecek bütün nesil için baki kılındığ1 görülür. Allah Teâlâ Kur'an'da insanı tavsifinde insanı şekillendirirken ruhundan üflediğini (Sâd, 38/72), ahsen-i takvim olarak tanımladığı şekli ile yarattığını (et-Tîn, 95/4) ve insanı yeryüzüne halife kıldığını (elBakara 2/30) belirtir. Bu ayetler ile birlikte insanı ele aldığımız zaman mükerremlik vasfını mutlak, dokunulmaz şekli ile insanın varlıksal değerinin bir ifadesi olarak tanımlayabiliriz.

28 Ebü's-Senâ Şihâbüddîn Mahmûd b. Abdillâh b. Mahmûd el-Hüseynî el-Âlûsî, Rûhu'l-me 'ânî fî tefsîri'l-Kur 'âni'l- 'aẓ̂m ve's-seb 'i'l-mesânn̂̀, tsh. Muhammed Hüseyin Arab (Beyrut: Dâru İhyai't-Türasi'l-Arabi, ts.), 15/117, Ebüssuûd Efendi, Tefsiru Ebüssuud = İrşadü'l-akli's-selim ila mezaya'l-Kur'ân-ı Kerim (Kahire: Dârü'l-Mushaf, ts.), $5 / 186$.

29 Burhânüddîn Mahmûd b. Ahmed b. Abdilazîz el-Buhârî el-Mergīnânî, el-Muhîțï'l-

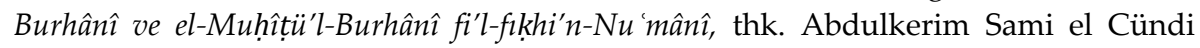
(Beyrut: Dârü'l-kütübi'l-ilmiyye, 1424/2004), 4/83.

30 Rıf'at Muhammed Mursî Tâhûn, Mevsûatu hukûki'l-insan fi'l-İslam (Beyrut: Darü'nNevadir, 2013/1434), 1/322-323. 
242 | N. Z. ŞAHİN / İnsanın Onuru mu? Mükerremliği mi? Biyoetikte İnsanın Değerinin Temellendirmesine Yönelik Bir Analiz

İnsanın onurunun kaynağı metafizik aleme bağlandığı zaman dini inanca sahip olmayanın insan onuru temelli bu haklardan faydalanıp faydalanamayacağına dair endişeyi Kohen dile getirmektedir. Kohen dini metinlerin insan haklarını içerdiğini söylemenin farklı; dini dünya görüşünün bu haklar için tek anlaşılır temel oluşturduğunu söylemenin ise daha farklı olduğunu belirtir. ${ }^{31} \mathrm{Bu}$ görüşe göre dini metinler üzerinden bu haklar temellendirilirse, hakkın temellendirildiği dini görüşe sahip olmayanların bu haklardan nasıl faydalanacağına dair bir sorunu da ortaya çıkartacaktır. Bu anlamda baktığımız zaman mükerremlik vasfı, insanı kendi dini inancından, dünya görüşünden bağımsız sadece insan olmasına dayanarak insana saygıdeğerlik yükleyen bir vasıf olduğunu söyleyebiliriz. Bu değerlilik insanın insan olmasından kaynaklandığı için insanın ilk oluşum aşamasından başlar ve ölümden sonraki süreçte de bu mükerremlik vasfı devam eder. Bu anlamda Peygamberimizin "ölünün kemiğini kırmak, onu diri iken kırmak gibidir." 32 buyruğu bu vasıf, ölümden sonra da bedeni koruyucu bir niteliği şeklinde okunmuştur.

Mükerremlik, kişiyi saygıdeğer kılan bir vasıftır. Müfessirler, insana neden bu vasfın yüklendiğine dair değerlendirme yaparken insanda bulunup da diğer varlıklarda bulunmayan özellikler üzerinde durmuşlardır. ${ }^{33}$ İnsanı diğer varlıklardan farklı kılan sadece insanda var olan hususiyetlerdir ki bunlar, akıl, bilinç ve temyiz gücüdür. Bununla birlikte insanın fiziksel yapısı da diğer varlıklardan insanı farklı kılan bir üstünlük olarak ortaya çıkmaktadır. ${ }^{34}$ Fahreddin er-Râzî (ö. 606/1210) insanın nefisten ve bedenden mürekkeb bir cevher olduğunu ve insan nefsinin yeryüzündeki nefislerin ve bedeninin yeryüzündeki bedenlerin

31 Ari Kohen, “The Problem of Secular Sacredness: Ronald Dworking, Michael Perry, and Human Rights Foundationalism", Journal of Human Rights 5 (2006), 235.

32 Ebû Dâvûd Süleymân b. el-Eş'as b. İshâk es-Sicistânî el-Ezdî, es-Sünen (Amman: Beytü'l-Efkari'd-Devliyye, ts.), “Cenâiz”, 58-60 (No. 3207).

33 Ebû İshâk İbrâhîm b. es-Serî b. Sehl ez-Zeccâc el-Bağdâdî, Me 'âni'l-Kur 'ân ve i 'râbüh, thk. Abdülcelil Abduh Şelebi (Beyrut: Âlemü'l-Kütüb, 1988/1408) 3/252.

34 Ebü'l-Kāsım Mahmûd b. Ömer b. Muhammed el-Hârizmî ez-Zemahşerî, el-Keşşâf 'an hakâa'iḳ ġavâmiżi't-tenzîl ve 'uyûni'l-ekāôil fì vücûhi't-te'vîl, thk. Halil Me'mun Şiha (Beyrut: Dârü'l-Ma'rife, 1430/2009), 603; Ebû Muhammed Muhyissünne el-Hüseyn b. Mes'ûd b. Muhammed el-Ferrâ' el-Begavî, Me 'alimü't-tenzîl, thk. Muhammed Abdullah en-Nemr vd. (Riyad: Dâru Taybe, 2. Basım, 1411), 5/108. 
en şereflisi olduğunu belirtir. ${ }^{35}$ Kurtubî (ö. 671/1273), keremli kılmayı insanın şerefli ve faziletli kılınması şeklinde açıklar. İnsanın diğer canlılardan farklı bir fiziksel yapı ile var edilmesi onun şerefli olarak yaratıldığının bir ifadesidir. ${ }^{36} \mathrm{Bu}$ yönü ile mükerremlik vasfı, insan olmakla bağlantılı bir vasıf olup elde edilmesi için yetenek veya çaba gerekli değildir. ${ }^{37}$ Mükerremlik vasfı, insanın kendisinin fillerinden, tercihlerinden bağımsız olarak kendi varlığı itibarı ile değerli olduğunu gösterir. Kişinin kendi varlığını korumada aciz olduğu anlarda da bu koruma şemsiyesi onun üzerinde devam etmektedir. İnsan onuru tanımlamasından farklı olarak bu yönü ile mükerremlik vasfı, insan türüne daha bütüncül bakış ve bütüncül bir koruma sağlamaktadır.

Mükerremlik vasfı insanı tür olarak diğer canlılardan ayrı bir muameleyi getirmektedir. Bu insana yönelik temel bir norm, âm bir hükümdür ve hükümler buna bağlı olarak verilir. Bu nedenle ehliyet, taharet, can güvenliği (el-masumiyetü'd-dem), ırzın, malın korunması ve defin işlemleri ve bunun dışındaki bir çok konular bu genel hükme bağlı olarak gelişmiştir. ${ }^{38}$ Bununla birlikte Hanefi içtihadı, insanın mükerremliğini âdemoğluna mensubiyetten kaynaklandığından hareket etmesiyle, insanın insan olmasından kaynaklanan temel haklarının bu kavram merkezinde tanımladıkları görülmektedir. ${ }^{39}$

\subsection{Muhteremlik Yönü İle Mükerremlik}

İslam hukukçuları insanı konuşurken, şâri'in insanı konumlandırdığı yerden onun korunması gereken bir değer olarak tanımlamıştır. Bu yönü ile insan için tanımlanan mükerremlik vasfı insanı, hukuken korunması gereken değerin bir ifadesi olan "muhterem" kılmıştır. Muhterem, onun mükerremliğine uygun olan bir

35 Ebû Abdillâh Fahrüddîn Muhammed b. Ömer b. Hüseyn er-Râzî et-Taberistânî, etTefsirü'l-kebir=Mefâtîhu'l-gayb (b.y.: Dârü'l-fikr, 1981), 21/13-14.

36 Ebû Abdillâh Muhammed b. Ahmed b. Ebî Bekr b. Ferh el-Kurtubî, el-Câmi' liahkâmi'l-Kur'ân, thk. Abdullah b. Abdülmuhsin et-Türki vd. (Beyrut: Müessesetü'rrisale, 2006/1427) 13/125-126.

37 Tuba Erkoç Baydar, "Fıkhî Açıdan İnsan Kavramı: Bezm-i Elesten Kabre İnsanın Mükellef Oluşunun Sebebi", İnsan Nedir? İslam Düşüncesinde İnsan Tasavvurları", ed. Ömer Türker - İbrahim Halil Üçer (İstanbul: İlim Yayınları, 2019), 486-487.

38 "Âdemiyye", Mevsûatü'l-fıkhi'l-İslâmî (Kuveyt: Vizaretü'l-Evkaf ve'ş-Şuuni'lİslâmiyye, 1983/1404) 1/95.

39 Recep Şentürk, Insan Hakları ve İslam Sosyolojik ve Fikhi Yaklaşımlar (İstanbul: İz Yayıncilık, 2017), 20-21. 
244 | N. Z. ŞAHİN / İnsanın Onuru mu? Mükerremliği mi? Biyoetikte İnsanın Değerinin Temellendirmesine Yönelik Bir Analiz

muamelenin hukuken bağlayıcı olan sınırının bir ifadesi olup insanı her türlü haksız fiilden korumakta ve insanın tür olarak kendisini bir araç haline dönüşmesini önlemekte, insan olmasından kaynaklı haklarının hukuken dokunulmazlığını getirmektedir.

İnsan yaşamı ve bedeni birlikte bir bütün olarak mükerremlik vasfi ile korunduğunun ön kabulü, onu muhterem, bugünkü dil ile hukuken korunan bir değer kılar. Bu bağlamda insanın mükerremliği insanın ve insanın uzuvlarının bir mal olmadığ şeklinde okunmuştur. ${ }^{40}$ Peygamberimizin hürün satılmayacağına dair yasağ $1^{41}$ ile bunu açıkça ifade etmiştir. İslam Hukukuna göre, insan bedeni mülk olmadığı için akid mahalli de değildir. İnsan bedeni üzerinde Allah hakkının ve kul hakkının birlikte yer alması ile birlikte Allah hakkının ağırlığı bedenin mülkiyetinin başkasına verme ve bir bedel karşılığın da satma hakkını da kişinin elinden almaktadır. ${ }^{42}$ İbn Âbidîn (ö. 1252/1836), insanoğlunun kafir bile olsa şer'an mükerrem olduğuna işaret eder Bu nedenle insanın akid konusu olması, onu cansızlar ile bir tutarak mükerremliğini yok etmek demektir. Harbinin ele geçirildikten sonra satılmasının mükerremliğinin ihlali olup olmadığına dair bir soru sorulacak olursa mükerremlik, insanın şeklinde ve yaratılışındadır. ${ }^{43}$ Kâsânî (ö. 587/1191) mal ile insanın değerini kıyaslayarak malın hurmetliğinin kendisi dışındaki nedene bağlı olduğuna fakat insanın hürmetliğinin ise insanın kendisininden kaynaklandığına ${ }^{44}$ işaretle bu vasfın insanda içkin olarak bulunduğunu belirtmektedir.

İnsanoğlu mükerrem olduğu için ondan ayrılan cüzleri de aynı mükerremliği taşımakta ve bu vasıf ona ait bütün cüzleri ile beraber onu bir değere dönüştürmekte, onu "muhterem" kılmaktadır. Bu nedenle Hanefi içtihadına göre insana ait cüzler mütekavvim mal değildir, satım

40 Şahin, “İslam Hukuku Açısından İnsan Kökenli Biyolojik Maddelerin Hukuki Statüsü", İslam Hukuku Araştırmaları Dergisi 13/25 (Nisan 2015) 214.

${ }^{41}$ Ebû Abdillâh Muhammed b. İsmâîl b. İbrâhîm el-Cu'fî el-Buhârî, el-Câmi 'u'ṣ-șahîhh, tsh. Mustafa Dib Buga (Dımaşk: Dâru İbn Kesir, 1993/1414), “Büyü'”, 106, (No. 2114).

42 Ebû İshâk İbrâhîm b. Mûsâ b. Muhammed el-Lahmî eş-Şâtıbî el-Gırnâtî, el-Muvafakat fî Usuli'ş-Şeria (Beyrut: Dâru'l kütübi'l-ilmiyye, 1991) 2/285.

43 Muhammed Emîn b. Ömer b. Abdilazîz el-Hüseynî ed-Dımaşkī, Reddü'l-muhtâr 'ale'd-Dürri'l-muhtâr, dirase, tahkik ve ta'lik Adil Ahmed Abdülmevcud - Ali Muhammed Muavvaz (Riyad: Dâru Âlemi'l-Kütüb, ts.), 7/245-246.

44 Alâüddîn Ebû Bekr b. Mes'ûd b. Ahmed el-Kâsânî, Bedâ'i 'u'ṣ-ṣanâ'i 'fî tertîbi'ş-şerâ'i (Beyrut: Dârü'l-kütübi'l-ilmiyye, 1986/1406), 7/258. 
akdine konu olamaz. ${ }^{45} \mathrm{~Hz}$ peygamberin "saç ekleten ve ekleyene Allah lanet etmiştir." 46 şeklinde gelen rivayette yasağın hukuki gerekçesi, insanın mükerremliğidir. ${ }^{47}$ İnsanın bütün cüzleri ile mukerrem ve muhterem olduğunu için alışverişe konu olması, onun bu muhteremliğine bir saygısızlık ifadesi olarak kabul edilmiştir. ${ }^{48}$

İnsanın bedenin mükerremliği onun beden mahremiyetinin bu saygınlığa dayanarak korunmasını getirir. İnsanoğlunun diri veya ölü fark etmeksizin mahremiyetini ihlal etmek, onun mükerremliğinin ihlali anlamina gelir. Kâsânî (ö. 587/1191), Bedâ'i 'u'ș-ṣanâ'i'de ölü bedenin bir bezle örtülmesi gerektiğini belirtir ve ölü bedenin müslüman olmasa da açılması mubah değildir. Çünkü ölü ve diri hali ile insan bedeni korunması gereken bir değerdir ve onun mahremiyetinin ihlali bu saygınlığın ihlali anlamına gelir. ${ }^{49}$

İnsan bedeninin dirisinin ve ölüsünün mukerrem olması bedene dokunulmazlık kazandırmıştır. Bununla birlikte, bir yaşamı kurtarmak ile ölü bir bedene zarar verme arasında kalındığı zaman, üst hukuki değer olan insan yaşamını korumanın tercih edilmesi gerektiğine dair değer içerikli bir değerlendirmenin de bu vasıf üzerinden yapıldığ1 görülmektedir. Hanefi fakihlerinden İbn Nüceym'in (ö. 970/1563), elEşbâh ve'n-nezâ'ir'de ölü olan anneden karnında canlı olan bir çocuğu çıkarmak için onun karnı yarılabilir hükmünü "Zarar zarar ile giderilmez ancak daha has zararlar ile daha umumi zararlar önlenir" külli kaidesini dayandırmıştır. Çünkü "İnsanoğlunun muhteremliği malın muhteremliğinden daha büyüktür." ${ }^{50}$ İnsanoğlunun kafir bile olsa ölü insan etinin zaruret halinde de yenilemeyeceğine dair görüş de insanın hürmetliğinin ihlalini engeleme üzerine kurulmuştur. ${ }^{51}$

45 Ebû Bekr Şemsü'l-eimme Muhammed b. Ebî Sehl Ahmed es-Serahsî, el-Mebsût (Beyrut: Dârü'l-Ma'rife, ts.) 15/125, 126.

46 Buhârî, "Libas", 83 (No. 5597).

47 Kâsânî, Bedâ'i 'u'ș-șanâ'i', 5/125.

48 Kemâlüddîn Muhammed b. Abdilvâhid b. Abdilhamîd es-Sivâsî el-İskenderî, Fetḥu'lkadîr li'l- 'âcizi'l-fakìr (Beyut: Dârü'l-kütübi'l-ilmiyye, 1424/2004) 6/390-391, Kâsânî, Bedâ'i 'u'ș-șanâ'i', 5 /145, 145.

49 Kâsânî, Bedâ 'i 'u'ș-șanâ'i', 1/300.

50 Zeynüddîn b. İbrâhîm b. Muhammed el-Misrî el-Eşbâh ve'n-nezẩ ir, thk. Muhammed Muti' Hafız (Dımaşk: Dârü'l-Fikr, 1983/1403), 76.

51 Ebû Abdillâh Muhammed b. Abdillâh b. Alî el-Haraşî el-Mâlikî, eş-Şerḥu'l-kebîr 'alâ Muhtașarı Halîl (Bulak: Matbaatü'l-Kübra'l-Emiriyye, h. 1317) 2/145-146. 
246 | N. Z. ŞAHİN/İnsanın Onuru mu? Mükerremliği mi? Biyoetikte İnsanın Değerinin Temellendirmesine Yönelik Bir Analiz

Fakihlerin insanın mükerremliği bağlamında yaptıkları bu değerlendirmelerin, organ nakli noktasında diri ve ölünün korunmasındaki maslahatsal içeriklerin belirlenmesinde öncül bir değerlendirme zeminini oluşturduğu görülmektedir. ${ }^{52}$

Bugün insan bedeninin ve ondan ayrılan cüzlerinin bir eşya gibi akde konu olup olmayacağını konuşur olmamız, insandan ayrılan maddelerin biyoteknolojinin gelişmesi ile birlikte tedavi ve araştırma amaçlı kullanılabilir veya bir ilacın hammaddesi haline dönüşebilir olmasıdır. Bu nedenle insandan alınarak saklanan, korunan ve teşhis ve tedavinin bir aracı haline dönüssen bu maddelerin insan kökenli biyolojik maddeler olarak adlandırılmasını ve hukuki statüsünün insanın kendisinden bağımsız olarak belirlenmeye çalışılmasını getirmiştir. ${ }^{53}$ Buna karşılık mükerremlik vasfı bedenin bütünlüğü içinde ele alındığ 1 takdirde, insan kökenli biyolojik maddelerinde insan varlığına ait olması yönü ile aynı saygınlık içinde ve bağlı olduğu hakları koruyucu bir şekilde hukuki düzenlemelere konu olacaktır.

Yardımcı üreme tekniklerinin gelişmesi ile de taşıyıcı annelik olarak bilinen insan bedeninin akid konusu olup olamayacağı da bu bağlamda ele alınabilecek diğer güncel bir konu olarak önümüzde durmaktadır. ${ }^{54}$ Rahmin akit konusu yapılması onu bir mal niteliğine dönüştüreceği için kadının mükerremlik vasfının ihlali anlamına gelir. Diğer taraftan taşıyıcı annelik başlangıçta rahmin kiralanması olarak görülse de hakikatte çocuğun satım akdidir. İslamiyette ise hürün satımı

52 İrfan İnce, “Organ Nakli”, Türkiye Diyanet Vakfı İslam Ansiklopedisi (Ankara: TDV Yayınları, 2007), 33/373; Diyanet İşleri Başkanlığı. “Din İşleri Yüksek Kurulu Başkanlığ1", Erişim 20 Şubat 2020, https://kurul.diyanet.gov.tr/Karar-MutalaaCevap/9669/organ-nakli; Ahmet Ekşi, "İslam Hukuku Bakımından Organ Nakli Etrafindaki Tartışmalar", İhya Uluslararası İslam Araştırmaları Dergisi 5/2 (2019), 386387.

53 Şahin, “İslam Hukuku Açısından İnsan Kökenli Biyolojik Maddelerin Hukuki Statüsü", 205-208.

54 Şahin, “Niçin Her Şey Satamayız? İnsanın Biyolojik Varlığı ve Biyolojik Maddelerinin Satım Akdine Konu Olabilirliğinin İsla Hukuku Açısından Değerlendirilmesi", 1. Uluslararası İslam Ekonomisi ve Finansı Kongresi Bildiri Kitabı, ed. Abdülkadir Atar (Karabük: Karabük Üniversitesi Yayınları, 2018), 427-428. 
yasaktır. ${ }^{55} \mathrm{Bu}$ yönüyle de insanın doğuştan getirdiği hürriyetin muhafazası onun mükerremliğinin muhafazası anlamına gelir.

Bugünkü biyoetik ikilemlerin çözümlenmesinde insan bedenine bütün olarak mükerremlik vasfı ile bakıldığı takdirde ona yönelik mükerremlik vasfını düşürücü her türlü fiil yasak kılınacak ve bu yönüyle bu vasıf insanın mükerremliğini koruma adına zarar ve fayda analizini daha doğru yapabilmeyi getirecektir.

\subsection{Fitratın Korunması Açısından Mükerremlik}

Mükerremlik vasfı insanın yaratılıştan getirdiği bir eşitliği göstermektedir. İnsanın yaratılıştaki eşitliğin ifadesi fitrattır. Fitrat, her insanın aynı tabiatta yaratıldığına işaret eder. Bu kavram yaratılıştaki safiyeti, üstünlüğü ifade eder ve insandan insana değişmediği için insana dair eşit davranışı da zorunlu kılar. İnsan fıtratı üzerinden tanımlanmış bir mükerremlik, insanın kendisini tanımladığı din, mezhep, meşrep, ırk diğer neler var ise onlardan arınmış olarak sadece yaratılış yönü ile insanların eşit olduğunun bir ifadesidir. Bu eşitlik bütün insanları hak ihlaline karşı koruyucu temel hakların kabulünü getirir. $^{56}$

İnsanın fitratı, insanın doğuştan gelen bütün özelliklerini ifade eden bir kelimedir.57 "Fitrat" kelimesi Rûm sûresi 30. âyetinde ${ }^{58}$ geçmektedir. $\mathrm{Bu}$ ayette geçen fitrat ile ilk yaratmadaki bozulmamış tabiat ifade edilmektedir. Bu yönü ile fitrat yaratılış ile eş anlamlı kelime olarak kabul edilmiştir. ${ }^{99}$ Fitrat ilk yaratılış sırasından Allah'ın insan tabiatına bahşettiği ruhundaki temizlik, yaratanını tanıma gibi olumlu özelliklerini ifade etmek için kullanıldığ kabul edilse de ${ }^{60}$ bu ilk yaratılış

55 Ömer Süleyman Eşkar vd., Dirasatun fikhiyye fì kazâyâ tıbbiyye muasıra (Amman: Dârü'n-Nefâis, 2001/1421) 2/812, 815.

56 Şaban Ali Düzgün, “İnsan Onuru Kaynağı Sınırı ve Temellendirmesi”, Hz Peygamber ve İnsan Onuru (Ankara: Diyanet İşleri Başkanlığı, 2013), 157.

57 Hayati Hökelekli, "Fıtrat", Türkiye Diyanet Vakfı İslam Ansiklopedisi (Ankara: TDV Yayınları, 1996), 13/47.

58 “Hakka yönelen bir kimse olarak yüzünü dine çevir. Allah'ın insanları üzerinde yarattığı fıtrata sımsıkı tutun. Allah'ın yaratmasında hiçbir değiştirme yoktur. İşte bu dosdoğru dindir. Fakat insanların çoğu bilmezler." er-Rûm 30/30.

59 Ebü'l-Hüseyn Ahmed b. Fâris b. Zekeriyyâ b. Muhammed er-Râzî el-Kazvînî elHemedânî, "Ftr", Mu'cemu mekayisi'l-luga, thk. Abdüsselam Muhammed Harun (Beyrut: Dârü'l-Fikr, ts.), 4/510.

60 Hökelekli, "Fitrat", 13/47. 
248 | N. Z. ŞAHİN / İnsanın Onuru mu? Mükerremliği mi? Biyoetikte İnsanın Değerinin Temellendirmesine Yönelik Bir Analiz

insanın fiziksel şeklinden bağımsız ele alınmamıştır. Taberî (ö. 310/923) Nisâ 119. âyetinde geçen "... Allah'ın yarattığını değiştirecekler.." ifadesini açılarken Rûm 30. ayetine gönderme yaparak Allah'ın yarattığ 1 beden üzerinde hadım, dövme gibi yollar ile yapılan değişikliğin bu ayet kapsamı içinde değerlendirileceğini belirtir. ${ }^{61}$ “Onları mutlaka saptıracağım, onları mutlaka kuruntulara sokacağım ve onlara emredeceğim de (putlara adak için) hayvanların kulaklarını yaracaklar. Yine onlara emredeceğim de Allah'ın yarattığını değiştirecekler...." (en-Nisâ, 4/119) şeklinde ayette geçen tağyir, önceden olmayan bir şeyin ortaya çıkartılmasıdır. ${ }^{62}$ Râgıb el-Isfâhâni (ö. V./XI. yüzyılın ilk çeyreği), tağyir kelimesinin iki anlamı olduğunu belirtir. Birinci anlamı ile bir şeyin aslı olmaksızın süretini değiştirmektir. İkincisi bir şeyi başka bir şey ile değiştirmektir. ${ }^{63}$ Ayette geçen hilkat veya yaratılış kelimesi ile de ifade edilenin yaratılışın maddi boyutu ile her şeyin fiziki durumunu, somut gözüken tarafını; manevi yönü ile de varlıkların görevlerini, işlevlerini ifade ettiği söylenebilir. Bu iki bilgi birlikte değerlendirildiği zaman fiziki anlamda yaratılanların yaratılışını ve manevi anlamda yaratılanların yaratılış amacını değiştirici bir işlevin bu yasağın içine girdiği görülür. ${ }^{64} \mathrm{Bu}$ anlamda insanın ilk yaratılışını değiştirmenin onun fitratını değiştirmek ve insanın fıtratını değiştirmenin ise üstün vasıflar ile yaratılan insanın mükerremlik vasfının korunamaması anlamına gelecektir. Çünkü insanoğlu "Biz insanı en güzel biçimde -ahsen-i takvim- yaratmışızdır" (et-Tîn 95/4) âyeti ile ifade edildiği şekli ile sadece insan türüne ait olan üstün vasıflar ile donatılmıştır. ${ }^{5}$ Âyette geçen "takvim” kelimesi bir şeyi doğrultmak, nizama koymak anlamina gelir. Buna göre "ahsen-i takvim" maddi ve manevi boyutu kapsayacak şekilde insanın yaratılması demektir. Bu ayeti Elmalılı Muhammed Hamdi (ö. 1878/1942) insan cinsinin maddeten ve manen doğrultmanın, kıvama koymanın,

${ }^{61}$ Ebû Ca'fer Muhammed b. Cerîr b. Yezîd el-Âmülî et-Taberî el-Bağdâdî, Câmiu'l-beyân fi tefsîri'l-Kur'ân (Beyrut: Müess'tü'r-Risâle, 1994/1415), 2/560-561.

${ }^{6}$ Ebü'l-Hasen Alî b. Muhammed b. Alî es-Seyyid eş-Şerîf el-Cürcânî, "Tağyir", etTa'rîfât, thk. Muahmmed Sıddık el-Minşavi (Kahire: Dârü'l-Fazile, ts.), 58.

63 Ebü'l-Kāsım Hüseyn b. Muhammed b. el-Mufaddal er-Râgıb el-İsfahânî, Müfredatu elfazi'l-Kur'ân, thk. Safvan Adnan Davudi (Dimeşk: Dârü'l-Kalem, 2009/1430), 619.

64 İsmail Yalçın, İslam Hukuku Açısından Yaratılışı Değiş̧tirme Fıtratı Bozma (Ankara: Fecr Yayinları, 2017), 14.

65 Musa Bilgiz, Kur'an'da İnsanlık Onuru (Ankara: Fecr Yayınları, 2012), 17. 
biçimlendirmenin en güzel biçimde yaratıldığının bir ifadesi olduğu şeklinde yorumlar. ${ }^{66} \mathrm{Bu}$ özelliğin insanın bedenine verildiğine dair bir örnek olarak Elmalılı Muhammed Hamdi zevcesine "sen kamerdan daha güzel olmamış isen boşsun" diyen kişiden talak vaki olmayacağına dair bu ayetten istidlal ile fetva verildiğini belirtir. ${ }^{67}$ Insanın yaratılış olarak en güzel biçimde yaratılması insana, yaratılıştan gelen bu üstün özelliklerini koruma sorumluluğunu yüklemektedir. $\mathrm{Bu}$ anlamda insanın yaratılışı ile birlikte insana verilen bu mükerremlik vasfı, estetik ameliyatlar ile yaratılıştan gelen bir çok özelliklerin değiştirebilir olduğu bir çağda, insanın kendi benliği ile barışmasını ve dünyaya gelişteki gerçek amacına odaklanmasını getirecektir.

Bugün insanın fitratının korunmasının mükerremlik vasfını koruyucu bir işlevi olacağını daha çok konuşur olmamız, insanın genetik haritasının çıkartılması, insan kopyalamanın gerçekleşebilir hale dönüşmesi, kök hücre çalışmalarının cidde bir ivme kazanması ve anne karnında kendi gelişimini devam ettiren cenine dışardan müdahalenin yapılabilir olması karşısında insan türünün kendi mirasını değiştirmeksizin gelecek nesillere aktarma endişesidir. BM 8 Mart 2005 yılında yayınladığı deklerasyonla insan onuruna yönelik olası tehlikelere işaret ederek, klonlamanın hem üreme hem de tedavi amaçlı olanını yasaklamıştır. ${ }^{6}$ Genetik bilimi ve biyoteknolojinin gelişmesi ile ortaya çıan insan türüne yönelik tehditlere insanlığı koruyucu bir vasıf olarak insanın fitratının korunması üzerine temellendirilen mükerremliğin, gelecek nesilleri de içine alacak şekilde kapsayıcı bir içeriğe sahip olduğunu bu bağlamda söylenebilir.

\section{3. Âdemiyyet Açısından Mükerremlik}

İnsanın doğuştan getirdiği haklar fikıh dili ile "'ismet" dokunulmazdır. Kelâmda "Allah'ın bir kimseyi günah ve hatadan korunması" ile özel bir anlam içeriği olan "ismet" kavramının fikıh literatüründe temel insan haklarını ifade de"eman, hak, hürmet, ihsan, zarûriyyât" terimlerinin yanında insanın dokunulmazlığını ifade için

66 Muhammed Hamdi Yazır, Hak Dini Kur'an Dili (İstanbul: Eser Neşriyat, 1979) 8/5935.

67 Yazır, Hak Dini Kur'an Dili, 8/5937.

68 United Nations (UN), “General Assembly Adopts United Nations Decleration on Human Clonning by Vote of 84-34-37", (Erişim 13 Ocak 2020). 
250 | N. Z. ŞAHİN / İnsanın Onuru mu? Mükerremliği mi? Biyoetikte İnsanın Değerinin Temellendirmesine Yönelik Bir Analiz

kullanıldığ1 görülmektedir. ${ }^{69}$ İsmet ile korunan hak, nesne veya kişiye korunmuş anlamina "ma'sûm", "mahkûn" veya "muhterem" ismi verilmiştir. ${ }^{70}$ Hukuk nazarında insanın canının korunmuşluğunun diğer bir ifadesi de can güvenliği anlamında "el-masumiyetü'd-dem"dir. Bu ilke sadece can güvenliğini değil bedene gelebilecek herhangi bir zarardan bedeni korumayı içerir. ${ }^{71}$

Hanefi içtihadında insanı korumanın kaynağı âdemiyyettir Hanefi içtihadı âdemiyyet kavramını 'ismet kavramı ile birleştirerek âdemin neslinden gelmenin doğuştan kazanılan temel insan haklarına sahip olmak için yeterli kabul etmiştir.72 Buna göre insanoğlunda asıl olanın hürriyet olması, şâri' tarafından verilen mükerremlik vasfının bir gereğidir. ${ }^{73}$ Kâsânî, Bedaiü's-sanai' de kölenin bir yönü ile mal bir yönü ile köle olduğunu söyleyenlerin bulunduğunu işaretle Hanefi görüşü olarak kölenin bütün yönleri ile Âdem olduğunu belirtir. Çünkü âdemiyyet $\mathrm{Hz}$ Âdem'e mensubiyeti ifade eden bir şahıs ismidir. Bu nedenle kölenin canının korunmuşluğu hür ile eş değer belki de daha üstün kabul edilmesi gerekir. ${ }^{74}$ İnsanoğlunun aslı, hür olduğu için üzerinde mülkiyet kurulamaz ve mal olarak ekonomik bir değer biçilemez. Köle olması yönü ise hukukendir ve hukuki gerekçe bitince kölelik biter, fakat âdemiyyet insan için temel bir vasıftır ve bu vasıf ölümden sonra da devam eder. ${ }^{75}$

Hanefi içtihadına göre insanoğlu teklifi hükümleri taşıyabilmesi için canı korunmuş olarak yaratılmıştır. Toplumda kötülüğün yayılmasını önlemek için verilen hukuki cezalar hariç insan için asıl olan, canının korunmuşluğudur. ${ }^{76}$ İnsanın âdemiyyet olarak haklarının

69 Recep Şentürk, “İsmet”, Türkiye Diyanet Vakfı İslam Ansiklopedisi (Ankara: TDV Yayınları, 2001) 23/137.

70 Şentürk, İnsan Hakları ve İslam, 39.

71 Ahmet Ekşi, İslam Tıp Hukuku Çă̆daş Tıp Problemlerine İslam'ın Getirdiği Hukuki Çözümler (İstanbul: Ensar Neşriyat, 2011) 60.

72 Şentürk, Insan Hakları ve İslam, 42.

73 Ebü'l-Fazl Mecdüddîn Abdullāh b. Mahmûd b. Mevdûd el-Mevsılî, el-İhtiyâr lita'lili'l-Muhtâr, thk. Mahmut Ebu Dakika (Beyrut: Dârü'l-kütübi'l-ilmiyye, ts.), 4/134.

74 Kâsânî, Bedâ'i 'u'ṣ-șanâ' ' ' fî̀ tertîbi'ş-şerâ'i', 7/238.

75 Kâsânî, Bedâ'i 'u'ș-ṣanâ'i', 5/290.

76 Ebû Muhammed Fahruddîn Osmân b. Alî b. Mihcen b. Yûnus es-Sûfî el-Bariî ezZeylaî, Tebyînü'l-hakãik fî şerhi Kenzi'd-dekãik (Bulak: el-Matbaatü'l-Kübra'l-Emiriyye, 1313), 3/245; Ekşi, İslam Tıp Hukuku, 60-65. 
korunmuşluğu, onun teklifi hükümleri yüklenebilmesi için gerekli kabul edilmiştir.77 Serahsî (ö. 571/1176), insan canının korunmuşluğunun zimmet akdine değil insan olma yönüne bağlı olduğunu, bu nedenle zimmet akdi kalksa da insanın canının korunmuşluğunun devam edeceğini belirtir. ${ }^{78}$ İnsanlar âdemiyyet sebebiyle aynı temel haklara sahiptir ve bu temel haklar onları din farkı gözetmesizin hepsini eşit kılmaktadır. ${ }^{79} \mathrm{Bu}$ korummuşluk, anne karnındaki cenini de kapsayacak şekilde ele alınır. Anne karnında ceninin düşmesine neden olunursa diri veya ölü olsun cenin düştüğü takdirde keffaretinin verilmesinin nedeni, insan muhterem olduğu için canının korunmuşluğuna dayandırıldığını görmekteyiz. ${ }^{80}$

Mükerremlik vasfının insan olmasından kaynaklanması bütün insanlar için eşit bir değer getirir. Kâsânî, Bedaiü's-sanai'de -belki de dönemin yaygın olan bir âdetine işaret ile- cenazeyi ellerinde taşımanın insanın mükerremliğinden kaynaklandığını belirtir. $\mathrm{Bu}$ nedenle hayvanın üzerinde cenazeyi taşımak, onun o değerini düşürmek anlamındadır. Çünkü hayvan üzerinde metâ taşınır; insan ise bir eşya değildir. Buna göre çocuğun cenazesi de aynı mükerremliğe sahip olduğu için elde taşınması gerekir. ${ }^{81}$

Mükerremlik vasfı, insanı kendi başına bir değer kılmaktadır. Serahsî, zina sonucu doğan çocuğun yapılan fiilden bağımsız olarak Allah'ın yarattığı bir kul olması ile mükerrem olduğunu ve bu yönü ile hürmetliğinin sabit olacağını belirtir. ${ }^{82}$ Zeylaî (ö. 743/1343) Tebyînü'lhakāik'de çocuğun hukuksal bir bağ içinde veya hukuksal bir bağ olmadan doğsun fark etmeksizin muhterem olduğunu ve bu vasfın ise çocuğa insan olarak yaratılması ile birlikte verildiğini ifade eder. ${ }^{83}$ Özellikle Hanefi içtihadının insanın mükerremliğini âdemiyyete

77 Zeylaî, Tebyînü'l-hakãik, 3/278.

78 Serahsi, el-Mebsut, 10/81.

79 Şentürk, İnsan Hakları ve İslam, 25.

80 Ebû Muhammed Muvaffakuddîn Abdullāh b. Ahmed b. Muhammed b. Kudâme elCemmâîlî el-Makdisî, el-Kâfî fî fikhi'l-İmâmi'l-Ahmed b. Hanbel, thk Muhammed Farisi (Beyrut: Dârü'l-kütübi'l-ilmiyye, 1994/1414), 4/51.

81 Kâsânî, Bedâ'i 'u'ș-ṣanâ'i', 1/309.

82 Ebû Bekr Şemsü'l-eimme Muhammed b. Ebî Sehl Ahmed es-Serahsî, Usûlü's-Serahsî, thk. Ebü'l-Vefâ el-Efganî (Haydarabad: Dâiretü'l-Maârifi'l-Osmaniyye, 1993/1414) $1 / 92$.

83 Zeylaî, Tebyînü'l-hakāik, 2/106. 
252 | N. Z. ŞAHİN / İnsanın Onuru mu? Mükerremliği mi? Biyoetikte İnsanın Değerinin Temellendirmesine Yönelik Bir Analiz

dayandırarak doğuştan gelen vasıflar yönü ile bütün insanların eşit olduğunu ortaya koymaya çalıştıkları görülmektedir.

\section{Sonuç}

Bir kavramın içeriği ona yüklenen anlamından, anlamın içeriği de kavramın var olduğu dünya düşüncesinden bağımsız değildir. Batı medeniyeti sekülerleştirdiği dünyada insanın değerini, insanın kendisine bağlayarak insan onurunu da seküler hale getirmiştir. Bu kavramsal içerik bireysel hakların talebinde insan onurunu, hakların temel dayanağı haline dönüştürmüştür. Bu nedenle birbirine zit hak talebinin temelini insan onuru oluşturmaya başlamış ve bu da bu kavramı içerik bakımından belirsizleştirmiştir. Diğer taraftan ise insan onurunun insan haklarının temel zeminini oluşturması, ondan vazgeçildiği takdirde insanın doğuştan getirdiği mutlak, dokunulamaz haklarının nasıl korunacağı sorusunu da hukukçu ve etikçilerin önüne birakmıştır.

İnsan haklarında ve biyoetikde insanı koyucu bir kavram olarak öne çıkan insan onuru kavramına karşılık İslamiyette insanın mükerremliği söz konusudur. İnsanın mükerremliği Kur'an'da âdemoğluna yüklenen bir vasıftır ve İslam hukukçuları tarafından içeriği insanı kendisine gelebilecek her türlü taşkınlıktan ve insan türünü değiştirici her türlü zarar verici fiillden koruyucu şekilde tanımlanmıştır. Bu kavram özne olarak insanı korumayı hedeflemektedir. $\mathrm{Bu}$ nedenle mükerremlik, İslam hukukçuları tarafından insanı koruyacak şekilde normatif bir nitelik kazandırılan bir kavramdır.

İnsan onuru muhatap odaklı olduğu için karşı taraftan talep içeren bir değerdir. Bu nedenle karşı taraftan hakkını talep edemeyecek olanlar için koruyucu şemsiyesi yeterli olamamaktadır. Mükerremlik vasfı ise özneye sorumluluk getirir ve bu vasıf insanın biyolojik yaşamsal sürecini ayırt etmeden âdemoğlu için kapsayıcı bir koruyuculuğu içerir. Bu yönü ile mükerremlik, özneyi korumaya doğru evrilen biyoetik için kavramsal içeriği bakımından insanı sadece insan varlığına ait olması yönü ile daha koruyucu bir vasfı ifade etmektedir. Bugün tıp, genetik ve biyolojinin getirdiği birçok farklı ikilemler karşısında insana tür olarak mükerremlik vasfı yüklendiği takdirde, sadece bugünün insanını değil 
gelecek nesillerinde bu mükerremlik vasfını kaybedebilecek her türlü etkiye karşı korunmasını getirecektir.

İnsan onurunun kaynağı insanın özerk seçimleridir. Bu da insanın kendi onurunu tanımlama ve nasıl korunacağını belirleme hakkını insanın kendisine vermektedir. Bu anlam içeriği içinde ki özerklik, insanın kendi bedeni üzerinde başkasına zarar vermediği müddetçe istediği işlemleri yapabileceği şeklinde bir sonucu ortaya çıkarmıştır. İnsanın mükerrem kılınması ise, ona yaratan tarafından verilen bir vasıf olması yönü ile, onu koruma sorumluluğu öncelikle insanın kendi bedenine karşı yerine getirmesi gereken bir görevi olarak tanımlanmıştır. Bu bağlamda hukuk düzenin de insanın mükerremliğini koruyacak şekilde düzenlemeler yapma yükümlügü bulunmaktadır.

İnsan onuru kişi olanlara ait bir vasıf olarak tanımlandığından henüz varlık aşamasına geçmemiş fakat insan olma potansiyeli taşıyan embriyo açısından koruyuculuğu ifade etmemektedir. Buna karşılık mükerremlik vasfı öncelikle insan kimliğinden bağımsız düşünülemez. Bu nedenle bütün insanları insan olmaları yönü ile bu saygıdeğerliliğin içine dahildir. Bu saygıdeğerlilik doğuş ile değil insan türüne ait olma yönü ile yaratılışın ilk aşamasından itibaren başlar. Çünkü bu vasıf insana değil insan türüne verilmiştir. Embriyo aşamasından başlayarak öldükten sonra da insan tür olarak mensubiyeti değişmeyeceği için saygıdeğerlilik vasfı da değişmemektedir. Ayrıca insanın biyolojik yaşamının her aşamasında mükerremlik, geçerli bir vasıftır. Bu nedenle insanın geçirdiği biyolojik aşamalardan birisi diğerine göre tıbbi desteğe daha çok hak sahibi diyerek gözden çıkartılabilecek bir yaşam söz konusu değildir.

İnsanın mükerremliği onun muhterem, hukuken korunan bir değer haline dönüştürmüştür. Bu değer insanın sadece kendine değil bedeninde yer alsa da almasa da cüzlerine de yüklenmiş ve bu vasıf yaşam ve ölüm fark etmeksizin insan bedenine has kılınmıştır. İslam hukukçuları insan söz konusu olduğu zaman mükeremliğin getirdiği muhteremlik ve masumiyet ile davranmışlardır. Bu nedenle insanın mükerremliği insan için korunması gereken hukuki bir değer olarak tanımlanması ile gelecek nesilleri de bu korumanın içine dahil etmişledir. Bu yönü ile mükerremlik vasfının biyoetik ikilemlerde insan türünü koruyucu bir niteliği olması yönü ile daha etkin ve işlevsel 
254 | N. Z. ŞAHİN / İnsanın Onuru mu? Mükerremliği mi? Biyoetikte İnsanın Değerinin Temellendirmesine Yönelik Bir Analiz

olacağını, insan onuruna göre içeriği daha belirgin ve tanımlanabilir bir kavram olduğunu belirtmek gerekir.

\section{Kaynakça}

"Âdemiyye". Mevsûatü'l-fikhi'l-İslâmî. 45 Cilt. Kuveyt: Vizaretü'l-Evkaf ve'ş-Şuuni'l-İslâmiyye, 1983/1404.

Âlûsî, Ebü's-Senâ Şihâbüddîn Mahmûd b. Abdillâh b. Mahmûd elHüseynî. Rûhu'l-me 'ânî fî̀ tefsîri'l-Kur'âni'l- 'azînm ve's-seb 'i'l-meșânî. tsh. Muhammed Hüseyin Arab. 31 Cilt. Beyrut: Dâru İhyai'tTürasi'l-Arabi, ts.

Baranzke, Heike. Batıdaki Biyomedikal Etik Tartışmalarında Özerklik ve İnsanlık Onuru. çev. M. Kemal Temel. İstanbul: Betim Beşikçizade Tip ve İnsani Bilimler Merkezi, 2018.

Barroso, Luís Roberto. "Here, There, and Everywhere: Human Dignity in Contemporary Law and in the Transnational Discourse". Boston College International and Comparative Law Review 35/2 (2012): 331393.

Beauchamp, Tom L. - Childress, James E. Biyomedikal Etik Prensipler. çev. Kemal Temel. 7. Basım. İstanbul: Betim Kitapliğı, 2017.

Begavî, Ebû Muhammed Muhyissünne el-Hüseyn b. Mes'ûd b. Muhammed el-Ferrâ'. Me 'âlimü't-tenzîl. thk. Muhammed Abdullah en-Nemr vd.. 8 Cilt. Riyad: Dâru Taybe, 2. Basım, 1411.

Beysan, Nazime. Hak Kavramının Hukuk Felsefesi Açısından Analizi. İstanbul: On İki Levha Yayıncılık, 2015.

Bilgiz, Musa. Kur'an'da İnsanlık Onuru. Ankara: Fecr Yayınları, 2012.

Buhârî, Ebû Abdillâh Muhammed b. İsmâîl b. İbrâhîm el-Cu'fî. elCâmi 'u'ṣ-șhịh. tsh. Mustafa Dib Buga. 6 Cilt. Dımaşk: Dâru İbn Kesir, 1993/1414.

Bulut, Nihat. "Eski Yunan'dan Aydınlanma Çağına İnsan Onuru Kavramının Gelişimine Genel Bir Bakış". Erzincan Üniversitesi Hukuk Fakültesi Dergisi 12/3-4 (2008), 1-12.

Burhâneddin el-Buhârî, Mahmûd b. Ahmed b. Abdilazîz el-Mergìnânî. el-Muhîtü'l-Burhânî fî́l-fikhi'n-Nu'mânî. thk. Abdulkerim Sami el Cündi. 9 Cilt. Beyrut: Dârü'l-kütübi'l-ilmiyye, 1424/2004.

Byk, Judge Christıan. “Is Human Dignity a Useless Concept? Legal Perspectives". The Cambridge Handbook of Human Dignity 
N. Z. ŞAHINN / Is The Human Dignity? Is el-Kerâmet'u-Nâs? An Analysis for Fundamentaling of Human Value in Bioethics I 255

Interdisciplinary Perspectives. ed. Marcus Düwell vd.. 362-367. Cambridge: Cambridge University Press, 2014.

Cürcânî, Ebü'l-Hasen Alî b. Muhammed b. Alî es-Seyyid eş-Şerif. etTa'rîfât. thk. Muahmmed Sıddık el-Minşavi. Kahire: Dârü'l-Fazile, ts.

Çelik, Elif. "İnsan Hakları Hukukunda İnsan Onurunun Yeri ve Önemi”. Hacettepe HFD 9/2 (2019), 282-310.

Çelik, Elif. İnsan Onurundan İnsanın Kırılganlığına: İnsan Haklarının

Temelinde Yatan Kavramları Yeniden Ele Almak. Ankara: Hacettepe Üniversitesi, Sosyal Bilimler Enstitüsü, Doktora Tezi, 2015.

DİB, Diyanet İşleri Başkanlığı. "Din İşleri Yüksek Kurulu Başkanlığı".

Erişim 20 Şubat 2020. https://kurul.diyanet.gov.tr/Karar-MutalaaCevap/9669/organ-nakli.

Düzgün, Şaban Ali. "İnsan Onuru Kaynağı Sınırı ve Temellendirmesi".

$\mathrm{Hz}$ Peygamber ve İnsan Onuru. 153-168. Ankara: Diyanet İşleri Başkanlığı, 2013.

Ebû Dâvûd es-Sicistânî, Süleymân b. el-Eş'as b. İshâk el-Ezdî. es-Sünen. Amman: Beytü'l-Efkari'd-Devliyye, ts.

Ebüssuûd Efendi. Tefsiru Ebüssuud = İrşadü'l-akli's-selim ila mezaya'lKur'ân-ı Kerim. 9 Cilt. Kâhire: Dârü'l-Mushaf, ts.

Ekşi, Ahmet. "İslam Hukuku Bakımından Organ Nakli Etrafındaki Tartışmalar". İhya Uluslararası İslam Araştırmaları Dergisi 5/2 (2019), 838-397.

Ekşi, Ahmet. İslam Tıp Hukuku Çă̆daş Tıp Problemlerine İslam'ın Getirdiği Hukuki Çözümler. İstanbul: Ensar Neşriyat, 2011.

Erkoç Baydar, Tuba. "Fıkhî Açıdan İnsan Kavramı: Bezm-i Elesten Kabre İnsanın Mükellef Oluşunun Sebebi". İnsan Nedir? İslam Düşüncesinde İnsan Tasavvurları. ed. Ömer Türker - İbrahim Halil Üçer. 467-500. İstanbul: İlim Yayınları, 2019.

Eşkar, Ömer Süleyman vd.. Dirasatun fikhiyye fî kazâyâ tıbbiyye muasıra. Amman: Dârü'n-Nefâis, (2001/1421).

Fahreddin er-Râzî, Ebü'l-Hasen Alî b. Ebû Abdillâh Muhammed b. Ömer b. Hüseyn. et-Tefsirüll-kebir=Mefâtîhu'l-gayb. 32 Cilt. b.y.: Dârü'l-fikr, 1981.

Gürbüz, Nagehan. Biyotıp Hukukunda İnsan Onuru. İstanbul: On İki Levha Yayıncilık, 2014. 
256 | N. Z. ŞAHİN / İnsanın Onuru mu? Mükerremliği mi? Biyoetikte İnsanın Değerinin Temellendirmesine Yönelik Bir Analiz

Haraşi, Ebû Abdullah Muhammed b. Abdullah el-Maliki. el-Haraşi ala Muhtasari Seyyidi Halil. Bulak: Matbaatü'l - Kübra'l-Emiriyye, h. 1317.

HHS, Office for Human Research Protections "The Belmont Report". Erişim 09 Nisan 2020. https://www.hhs.gov/ohrp/regulations-andpolicy/belmont-report/read-the-belmont report / index.h tml.

Hökelekli, Hayati. "Fitrat". Türkiye Diyanet Vakfi İslam Ansiklopedisi. 13/47-48. Ankara: TDV Yayınları, 1996.

İbn Âbidîn, Muhammed Emîn b. Ömer b. Abdilazîz el-Hüseynî edDımaşkī. Reddü'l-muhtâr 'ale'd-Dürri'l-muhtâr. thk. Adil Ahmed Abdülmevcud - Ali Muhammed Muavvaz. 13 Cilt. Riyad, Dâru Âlemi'l-Kütüb, ts.

İbn Fâris, Ebü'l-Hüseyn Ahmed b. Zekeriyyâ b. Muhammed er-Râzî elKazvînî el-Hemedânî. Mu'cemu mekayisi'l-luga. thk. Abdüsselam Muhammed Harun. 6 Cilt. Beyrut: Dârü'l-Fikr, ts.

İbn Kudâme, Ebû Muhammed Muvaffakuddîn Abdullāh b. Ahmed b. Muhammed el-Cemmâîlî el-Makdisî. el-Kâfî fî fikhi'l-İmâmi'lAhmed b. Hanbel. thk Muhammed Farisi. 4 Cilt. Beyrut: Dârü'lkütübi'l-ilmiyye, 1994/1414.

İbn Nüceym, Zeynüddin b. İbrâhim b. Muhammed el-Mısrî. el-Eşbâh ve'n-Nezâir. thk. Muhammed Muti' Hafız. Dımaşk: Dârü'l-Fikr, 1983/1403.

İHD, İnsan Hakları Derneği. “İnsan Hakları Evrensel Bildirgesi”. Erişim 13 Şubat 2020.

İsfahânî, Ebü'l-Kâsım Hüseyin b. Muhammed b. Mufaddal er-Râgib. Müfredatu elfazi'l-Kur'ân. thk. Safvan Adnan Davudi. Dimeşk: Dârü'l-Kalem, 2009/1430.

Kalkan Oğuztürk, Burcu. Türk Medeni Hukukunda Biyoetik Sorunlar. İstanbul: Vedat Kitapçılık, 2011.

Kâsânî, Alâüddîn Ebû Bekr b. Mes'ûd b. Ahmed. Bedâ'i 'u'ṣ-șanâ'i fî tertîbi'ş-şerâ'i' 7 Cilt. Beyrut: Dârü'l-kütübi'l-ilmiyye, 1986/1406.

Kohen, Ari. "The Problem of Secular Sacredness: Ronald Dworking, Michael Perry and Human Rights Foundationalism". Journal of Human Rights 5 (2006), 235-256.

Kurtubî, Ebû Abdillâh Muhammed b. Ahmed b. Ebî Bekr b. Ferh. elCâmi 'li-ahkâmi'l-Kur'ân. thk. Abdullah b. Abdülmuhsin et-Türki vd.. 24 Cilt. Beyrut: Müessesetü'r-risale, 2006/1427. 
N. Z. ŞAHINN / Is The Human Dignity? Is el-Kerâmet'u-Nâs? An Analysis for Fundamentaling of Human Value in Bioethics I 257

Macklin, Ruth. "Dignity is a useless concept". British Medical Journal 327/20-23 (2003), 1419-1420.

Mevsilî, Ebü'l-Fazl Mecdüddîn Abdullãh b. Mahmûd b. Mevdûd. elİhtiyâr li-ta'lili'l-Muhtâr. thk. Mahmut Ebu Dakika. Beyrut: Dârü'lkütübi'l-ilmiyye, ts.

O'neill, Onora. Autonomy and Trust in Bioethics. Cambridge: Cambridge University Press, 2004.

Perry, Michael J. The Idea of Human Rights. Oxford: Oxford University Press, 1998.

Rao, Neomi. "The Trouble with Dignity and Rights of Recognition". Virginia Law Review 99/1 (2013), 29-38.

Rao, Neomi. "Three Concepts Of Dignity In Constitutional Law". Notre Dame Law Review 86/1 (2011), 183-271.

Serahsî, Ebû Bekr Şemsü'l-eimme Muhammed b. Ebî Sehl Ahmed. elMebsût. Beyrut: Dârü'l-Ma'rife, ts.

Serahsî, Ebû Bekr Şemsü'l-eimme Muhammed b. Ebî Sehl Ahmed. Usûlü's-Serahsî. thk. Ebü'l-Vefâ el-Efganî. 2 Cilt. Haydarabad: Dâiretü'l-Maârifi'l-Osmaniyye, 1993/1414 .

Şahin, Nurten Zeliha. "Niçin Her Şey Satamayız? İnsanın Biyolojik Varlığı ve Biyolojik Maddelerinin Satım Akdine Konu Olabilirliğinin İsla Hukuku Açısından Değerlendirilmesi". 1. Uluslararası İslan Ekonomisi ve Finansı Kongresi Bildiri Kitabı. ed. Abdülkadir Atar. 422-432. Karabük: Karabük Üniversitesi Yayınları, 2018.

Şahin, Nurten Zeliha. "İslam Hukuku Açısından İnsan Kökenli Biyolojik Maddelerin Hukuki Statüsü". İslam Hukuku Araştırmaları Dergisi 13/25 (Nisan 2015), 205-223.

Şahin, Nurten Zeliha. "İslam Hukuku ve İnsan Hakları Bağlamında Eşcinsellik Sorunu". Ekev Akademi Dergisi 19/62 (Bahar 2015), 507530.

Şentürk, Recep. “İsmet”. Türkiye Diyanet Vakfi İslam Ansiklopedisi. 23/137138. Ankara: TDV Yayınları, 2001.

Şentürk, Recep. İnsan Hakları ve İslam Sosyolojik ve Fıkhi Yaklaşımlar. İstanbul: İz Yayıncılık, 2. Basım, 2017.

Taberî, Ebû Ca'fer Muhammed b. Cerîr b. Yezîd el-Amülî. Câmiu'l-beyân fi tefsîri'l-Kur'ân. 7 Cilt. Beyrut: Müess'tü'r-Risâle, 1994/1415. 
258 | N. Z. ŞAHİN / İnsanın Onuru mu? Mükerremliği mi? Biyoetikte İnsanın Değerinin Temellendirmesine Yönelik Bir Analiz

Tâhûn, Rif'at Muhammed Mursî. Mevsûatu hukûki'l-insan fi'l-İslam. Beyrut: Darü'n-Nevadir, 2013/1434.

TDK, Türk Dil Kurumu Sözlükleri. "Onur". Erişim 30 Ocak 2020. https://sozluk.gov.tr.

UN, United Nations. "General Assembly Adopts United Nations Decleration on Human Clonning by Vote of 84-34-37". Erişim 13 Ocak 2020. https://www. un. Org/press/e /2005/ga 10333.doc.htm.

WHO, Islamic Code of Medical and Health Ethics. "World Health Organization Regional Office for the Eastern Mediterranean". Erişim 09 Nisan 2020. http://applications. emro. who. int/ docs/EM_RC52_7_en.pdf.

Yalçın, İsmail. İslam Hukuku Açısından Yaratılışı Değiştirme Fıtratı Bozma. Ankara: Fecr Yayınları, 2017.

Yazır, Muhammed Hamdi. Hak Dini Kur'an Dili. 10 Cilt. İstanbul: Eser Neşriyat, 1979.

Zeccâc, Ebû İshâk İbrâhîm b. es-Serî b. Sehl el-Bağdâdî. Me 'âni'l-Kur'ân ve i 'râbüh. thk. Abdülcelil Abduh Şelebi. 5 Cilt. Beyrut: Âlemü'lKütüb, 1988/1408.

Zemahşerî, Ebü'l-Kāsım Mahmûd b. Ömer b. Muhammed el-Hârizmî. el-Keşşaf 'an hakâ'ikı gavâmizi't-tenzil ve 'uyûni'l-ekâvil fî vücuhi'tte'vîl. thk. Halil Me'mun Şiha. Beyrut: Dârü'l-Ma'rife, 1430/2009.

Zengin, Mehmet Ali. Biyoloji Uygulamalar ve Tıbbi Müdahaleler Karşısında İnsan Haklarının Korunması. Ankara: Adalet Yayınevi, 2012.

Zeylaî, Ebû Muhammed Fahruddîn Osmân b. Alî b. Mihcen b. Yûnus esSûfî el-Bariî. Tebyînü'l-hakãik fî şerhi Kenzi'd-dekãik. 6 Cilt. Bulak: elMatbaatü'l-Kübra'l-Emiriyye, 1313. 